\title{
Expression of OCT4 Stem Cell Marker in Benign Prostatic Hyperplasia and Normal Tissue Around the Prostatic Carcinoma in a Sample of Iraqi Patients
}

\section{Original Article}

\author{
Khalida I. Noel', Mustafa M. Ibraheem ${ }^{1}$, Basim S. Ahmed ${ }^{2}$, Ahmed F. Hameed', \\ Nibras H. Khamees ${ }^{l}$, Sameh S. Akkila ${ }^{l}$
}

${ }^{1}$ Department of Anatomy, ${ }^{2}$ Department of Pathology, College of Medicine, Al-Mustansiriyah University, Baghdad

\begin{abstract}
Objective: Prostatic diseases (benign and malignant) are broadly widespread in the world. Benign prostatic hyperplasia is a chronic entity reflected by enlarged prostatic tissue, triggering inferior urinary tract complaints. On the other hand, prostate cancer, is the second most common cancer in men and the fourth utmost commonly happening cancer generally. OCT4 referred to as octamer binding transcription factor 4, also recognized as POU5F1 (POU domain class 5 transcription factor 1 ), is a protein that in humans is coded by the POU5F1 gene. This protein is analytically elaborate in the self-renewal of undifferentiated embryonic stem cells. As such, our work is designed to evaluate the immunohistochemical examination of OCT4 expression in the prostatic epithelium in cases of benign prostatic hyperplasia (BPH) and in the epithelium of prostatic adenocarcinoma microenvironment (NPCA).

Patients and Methods: The prostate samples were acquired from $50 \mathrm{BPH}$ patients, and 50 prostatic cancer patients. The samples were managed for immunohistochemical examination of OCT4 expression.

Results: Statistical analysis revealed significant difference in the staining percentage between the BPH and NPCA group $(P$-value $=0.009)$, and there was significant staining expression of OCT4 in NPCA group as compared to BPH group $(P$-value $=0.000)$. Also, there was significant elevation of the total score of OCT4 in NPCA group $(P$-value $=0.036)$ as compared with $\mathrm{BPH}$ group.

Conclusions: OCT4 is over expressed in normal tissue around prostatic carcinoma as compared to benign tissue in BPH, and thus OCT4 can be used as a stem cell marker for prostatic tissue tuomorigenicity.
\end{abstract}

Received: 18 June 2019, Accepted: 21 September 2019

Key Words: BPH, immunohistochemistry, OCT4, prostatic cancer.

Corresponding Author: Khalida I. Noel, PhD, Human Anatomy Departement, College of Medicine, Mustansiriyah University, Baghdad, Iraq, Tel.: +964 7701658890, E-mail: khalidanoel79@gmail.com

ISSN: $1110-0559$, Vol. 43, No. 1

\section{INTRODUCTION}

Benign prostatic hyperplasia is a chronic entity reflected by enlarged prostatic tissue, triggering inferior urinary tract complaints. The prevalence rises from nearly $50 \%$ at age of 60 to $90 \%$ in males older than 85 years $^{[1]}$.

On the other hand, prostate cancer, is the second most common cancer in men and the fourth utmost commonly happening cancer generally. There were 1.3 million new cases in 2018 appeared all over the world ${ }^{[2]}$. The number of new cases rises every year, while the rate of mortality is quite continuous. This can be credited to the fact that diagnostic procedures for early recognition of this disease are enhanced and allow earlier stages of the disease to be confined ${ }^{[3]}$.

There are several genetic, hormonal, and inflammatory mechanisms that have all been displayed to be common pathophysiological active mechanisms for the appearance of both $\mathrm{BPH}$ and prostatic carcinoma (PCa), thus linking these diseases together ${ }^{[1]}$. However till now, on a cellular and molecular points, there is no clear cut data for change of BPH tissue into an oncological disease which is the principle aim of the current study. Furthermore, more research is required to fully expose the underlying molecular pathways behind prostatic diseases. This is essential to improve future treatment plans for both diseases $^{[3]}$.

OCT4 referred to as octamer binding transcription factor 4, also recognized as POU5F1 (POU domain class 5 transcription factor 1 ), is a protein that in humans is coded by the POU5F1 gene. This protein is analytically elaborate in the self-renewal of undifferentiated embryonic stem cells ${ }^{[4]}$. As such, it is usually used as an indicator for undifferentiated cells. Expression of OCT4 must be thoroughly organized; higher or lower level will cause differentiation of the cells ${ }^{[5]}$. However, OCT4 isoforms could be recognized also, and they differ in their expression; that OCT4B is expressed in the cytoplasm of cells, while OCT4A seen in the nucleus ${ }^{[5]}$. Both isoforms have the same DNA with its $\mathrm{C}$ terminal domains, but differ in $\mathrm{N}$ terminal domains $^{[5]}$. 
It is well documented that higher expression of OCT4, Nanog and SOX2, separately or together could lead to tumorigenicity, cancer metastasis, and sometimes distant relapse after chemoradiotherapy in many kinds of cancer ${ }^{[6,7]}$. Over expression of OCT4 was noticed in Prostate cancer ${ }^{[8]}$ and Breast tumor stem cells ${ }^{[9]}$. OCT4 plays a serious part in the existence of these cancer cells. In general, these transcription factors are mainly repeatedly highly expressed in poorly differentiated cancers; if compared to those well differentiated malignancy and expression level of these "stemness" related factors drops with the more differentiation of cells ${ }^{[10]}$.

\section{AIMS OF THE STUDY}

This study aimed to assess the difference in OCT4 expression in BPH and prostatic carcinoma microenvironment.

\section{Methods}

\section{Patients}

The present work started from February 2018 to March 2019 in Al- Yarmok teaching hospital in Baghdad city of Iraq (histopathology unit) with two private histopathological labs. The revision was conducted on human prostatic tissue specimens received from patients attending this hospital.

A total number of 100 specimens were selected for the study, some were prospective, with a majority of retrospective samples acquired from archives of histopathology units of those labs and hospital.

\section{The specimens were divided as follows}

Fifty primary prostatic carcinoma tissue samples were obtained from surgical resection of the prostate, normal prostatic tissues excised within the safety margin (NPCA) (normal epithelial specimens $\geq 5 \mathrm{~cm}$ distant from the tumor margin, which is from the intact tissue during the operation) ${ }^{[11]}$, These specimens featured Gleason scores from 6 to 10 and fifty tissue samples comprising benign prostatic hyperplasia (BPH) were gained from transurethral resection surgery.

Patients were divided into two groups namely normal adjacent to cancer (NPCA) including 50 patients known to have prostatic adenocarcinoma, their age ranged from 5582 years with mean age 70 years. Another 50 patients who had BPH and their age range between $60-86$ years with mean age 71 years.

Ethical agreement for the work was gained from the ethical committee of Al-Yarmok teaching hospital supported by written consent from the patients. The pathological diagnosis of prostatic carcinoma and $\mathrm{BPH}$ was established by reviewing a freshly prepared haematoxylin and eosin stained slides

\section{Immunohistochemistry}

For each sample 2 serial sections were selected, each with 4 micrometers thickness. The first section was placed on an ordinary slide and stained by haematoxylin and eosin stain to confirm the diagnosis and to define the histological types and grades for the tumor. The second section was placed on the positively charged slide for immunohistochemical staining with anti-OCT4 antibody (Primary antibody from Abnova, Gene ID: 5460|18999|294562, Code PAB12773, Rabbit anti-human polyclonal raised against synthetic peptide of POU5F1, no specific isoform). The secondary detection kit (Abcam) code ab64261 rabbit specific HRP/ DAB were used.

Formalin fixed samples and paraffin embedded tissue sections were dewaxed using xylene, and progressively hydrated. Antigen retrieval was done by pressure cooking using citrate buffer for 20 minutes. The primary anti-OCT4 antibody was diluted as 1:200 using a reducing dilution buffer (Abcam code ab64211) and kept warm at room temperature for 30 minutes $^{[12]}$.

Detection achieved by means of labeled streptavidinbiotin from Abcam secondary detection kit, followed by $\mathrm{DAB}$ and chromogen staining. The slides were briefly counterstained with haematoxylin and mounted by DPX ${ }^{[12]}$.

\section{Evaluation of the immunohistochemical staining}

All tissues were evaluated blindly (without prior knowledge of the type of the sample or the age of the patient). Anti-OCT4 staining showed distinct nuclear brown IHC staining.

The accuracy of the positive and strongly positive categories was further tested and confirmed by ranking each slide from the lowest to highest intensity and extent of staining and location was also revealed for each marker. The slides were examined with low power microscope 10X to determine the regions of highest staining, if they show no staining at low power re-examination was done by high power 40X to determine area of weak staining, 5 fields of each slide were examined and scored semiquantitatively by calculating the proportion of positive staining cells over the total number of cells examined (\%) and samples were graded according to the extent of staining and intensity ${ }^{[13]}$.

The index was evaluated by multiplying the cell percentage with the intensity. Indices were determined by counting the number of positive nuclei among $\geq 300$ cells in high-power fields and were indicated as percentages. Positive cells were evaluated for their intensity of immunoreactivity on a $0-3+$ scale.

Percentage and intensity of staining were calculated as follows ${ }^{[14]:}$

Staining intensity was given scoring as:

0 (no staining), $1+$ (weak), $2+$ (moderate) and $3+$ (strong).

Staining extent (percentage) was categorized by percentage:

$0=$ nil, $1=<10 \%$ of cell stained positively, $2=10-50 \%$, $3=>50 \%$ 
Final IHS (total score) calculated by multiplying the intensity by percentage $(0-3)^{[13]}$

These was done by using double blind method for calculating both intensity and percentage and confirmed by using computerized (Immunohistochemical Profiler Plugin and Macro in Image J) method.

\section{Quality Control}

\section{Positive control}

Human adrenal gland tissue was used as a positive control for OCT4 which had been confirmed to overexpress OCT4[14].

\section{Negative control}

It was done by deleting the primary antibody and adding antibody diluent alone in the same slide and follows the same steps in $\mathrm{IHC}^{[13]}$.

\section{Statistical analysis}

Statistical analysis was achieved by using the SPSS (Statistical Packages for Social Sciences) V24 .Categorical variables were evaluated by evaluation of percentage, mean, and range (min-max values). The qualitative data were examined using Pearson Chi-square test (X2 -test), and independent sample t-test.

\section{RESULTS}

\section{Age distribution}

The mean age of BPH group was $(71.14 \pm 6.3)$ with the range of (60-86 years). The mean age of NPCA group was (69.76 \pm 7.9$)$ with the range of (55-82 years). There were no statistical significance among the mean age of these groups $(p$ value $=0.097)($ Figure 1$)$.

\section{Immunohistochemical (IHC) expression of OCT4}

\section{The staining percentage of OCT4}

OCT4 is a nuclear expressed marker, the percentage of staining of OCT4 in BPH group was $(36.7 \pm 32.93)$, while in the NPCA group was (51.9 \pm 22.97$)$. Therefore comparing the percentage of staining between the two groups was statistically significant $\mathrm{P}$-value $=0.009$, with OCT4 was more expressed in the NPCA group as stated in (Figure 2).

\section{The staining intensity of OCT4}

In $\mathrm{BPH}$ group, there were 18 out of 50 samples (36\%) that showed the negative expression (0) of OCT4. On the other hand, 15 out of 50 samples $(30 \%)$ displayed weak expression (1+) of OCT4 stem cell marker. Moderate staining expression $(2+)$ were obtained in 10 out of 50 samples of BPH group $(20 \%)$, while strong staining intensity $(3+)$ were exhibited in 7 out of 50 samples $(14 \%)$. The intensity scores are shown in (Figures 3 and 4) and the intensity of OCT4 epithelial cells expression in BPH tissue are shown in (Figures 5-8).
In NPCA group, only 1 out of 50 samples (2\%) showed no expression of OCT4 (0). Whereas 15 out of 50 samples $(30 \%)$ showed weak intensity $(1+)$ of OCT4, and 25 out of 50 samples $(50 \%)$ moderately express OCT4 $(2+)$. On the other hand, 9 out of 50 NPCA samples (18\%) displayed strong staining intensity $(3+)$ of OCT 4 stem cell marker. The intensity scores are shown in (Figures 3 and 4 ) and the intensity of OCT4 epithelial cells expression in BPH tissue are shown in (Figures 9-12).

Therefore, OCT4 had more intense positive signals (2+, $50 \%$ ) in the NPCA group than in the BPH group and the difference was statistically significant with $P$-value $=0.000$ as shown in (Figure 3).

\section{The total score of OCT4}

Total score of 50 samples in BPH group, the mean and standard deviation of OCT4 marker was $(0.71 \pm 0.28)$, and in the NPCA group (50 samples) was $(1.06 \pm 0.77)$. So, OCT4 had a higher score in the NPCA group $(P$-value $=0.036)$ as appeared in (Figure 4).

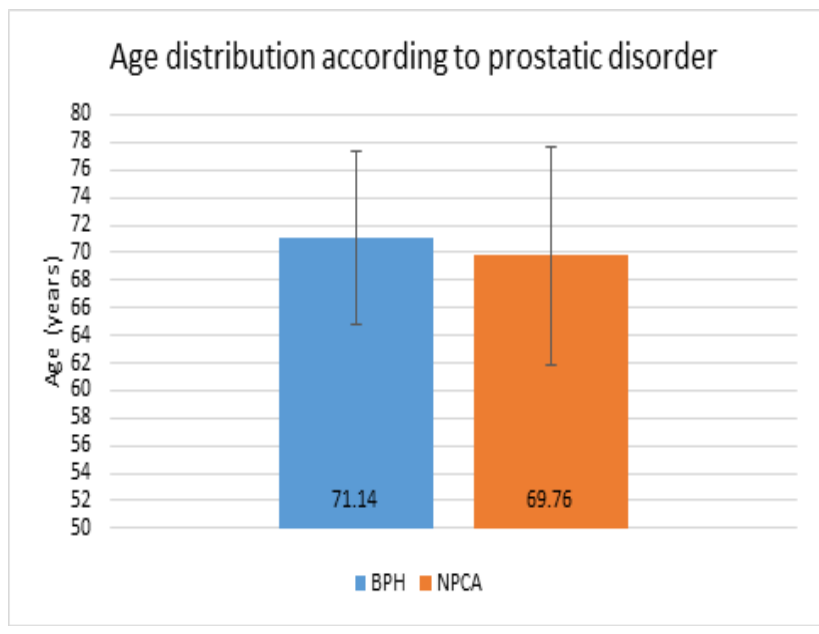

Fig. 1: Age distribution according to prostatic disorder (Bars represent mean \& error bars $=$ standard deviation)

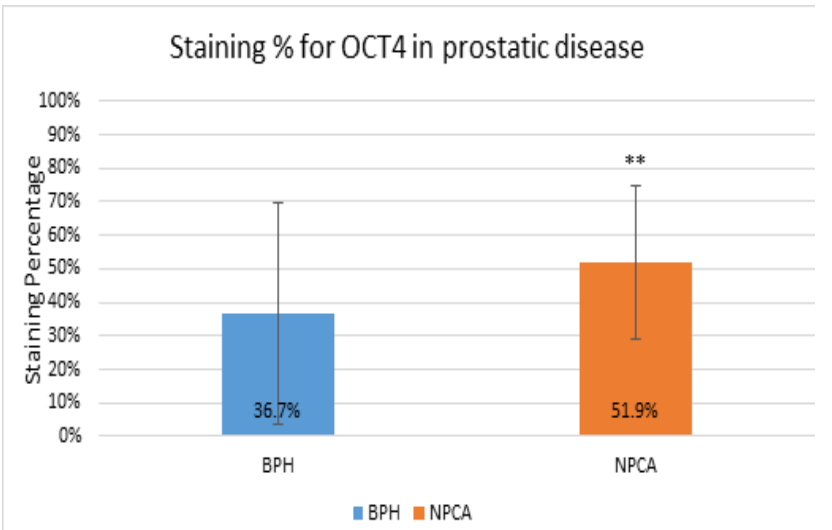

Fig. 2: OCT4 staining percentage according to prostatic disease. $* *=P$-value $<0.01$ 


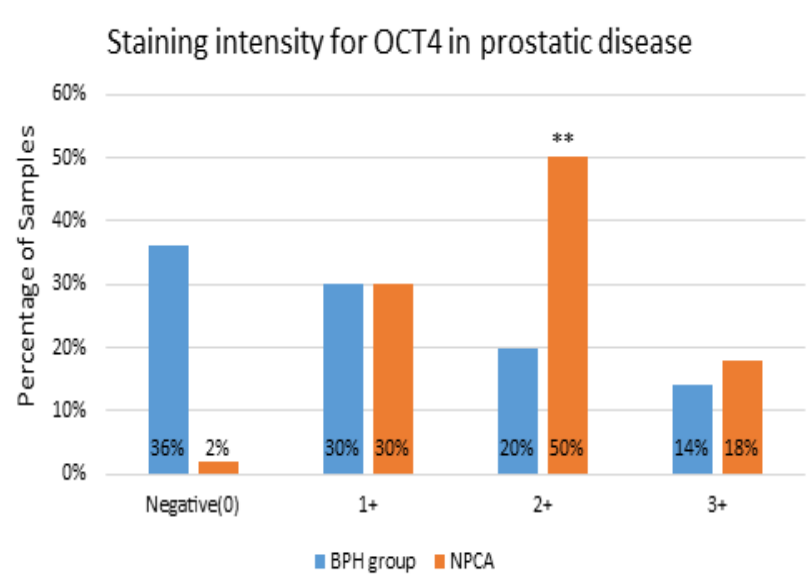

Fig. 3: Staining intensity of OCT4 according to prostatic disease. $* *=\mathbf{P}$-value $<0.01$

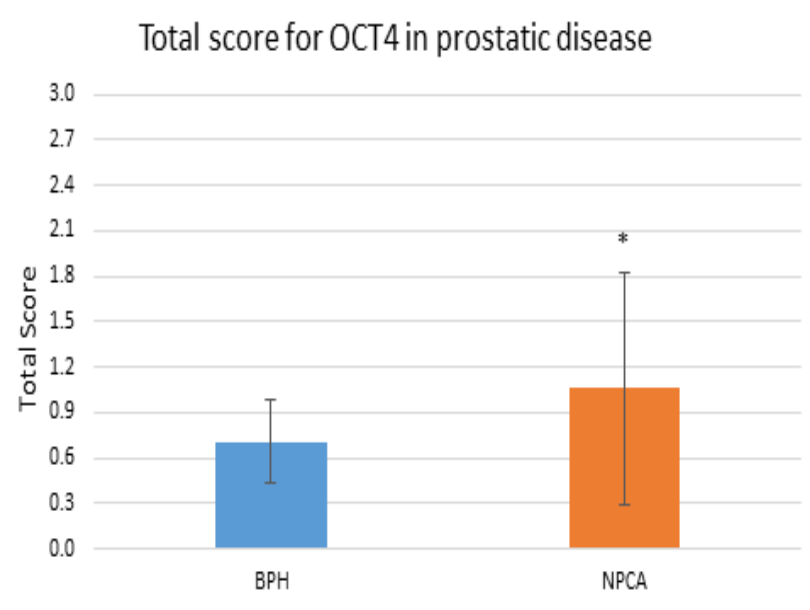

Fig. 4: Total score of OCT4 expression in prostatic disease. $*=P$-value $<0.05$

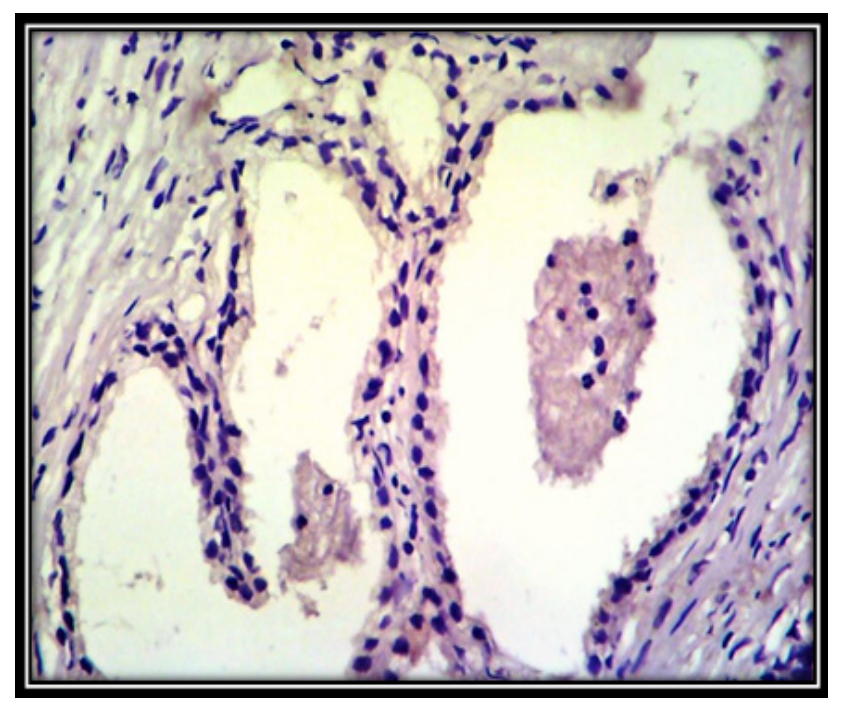

Fig. 5: Negative immunohistochemical expression of OCT4 in prostatic cell nuclei of BPH group. X400

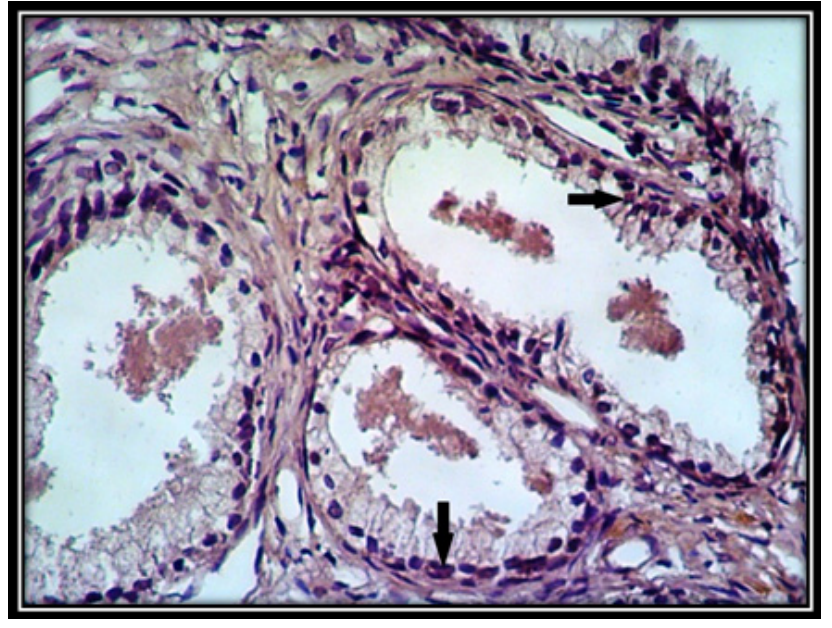

Fig. 6: Immunohistochemical expression of OCT4 in BPH tissue shows 1+ weak nuclear reactivity (black arrows) of OCT4 polyclonal antibody. X400

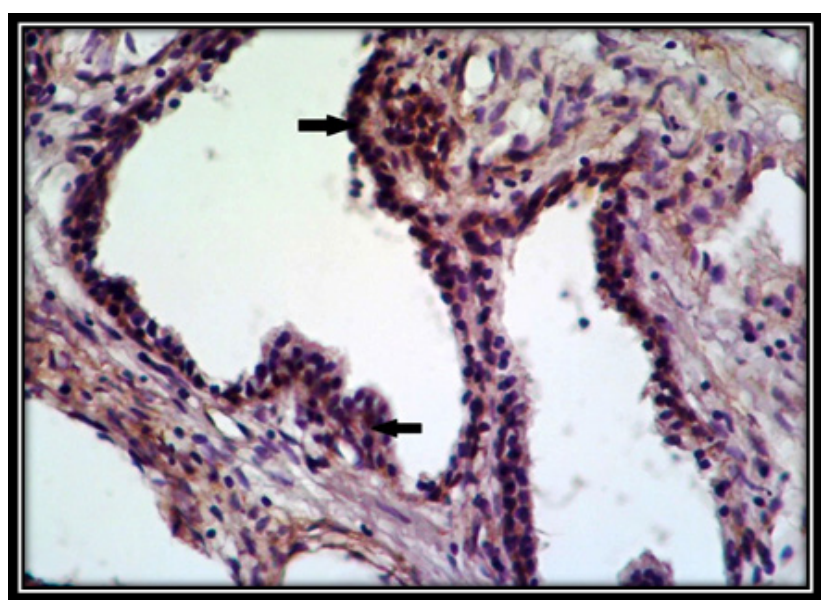

Fig. 7: Immunohistochemical expression of OCT4 in BPH tissue shows $2+$ nuclear moderate reactivity (black arrows) of OCT4 polyclonal antibody. X400

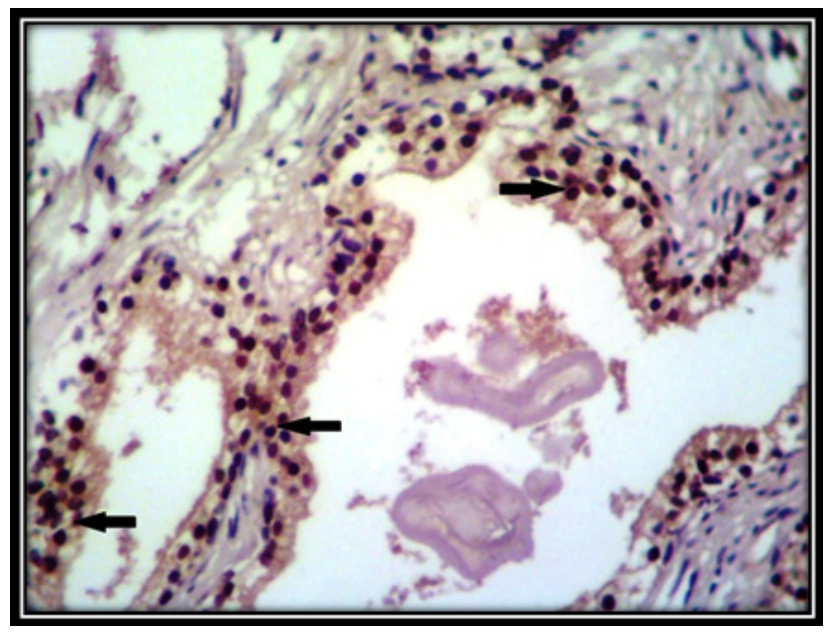

Fig. 8: Immunohistochemical expression of OCT4 in BPH tissue shows $3+$ strong nuclear reactivity (black arrows) of OCT4 polyclonal antibody. X400 


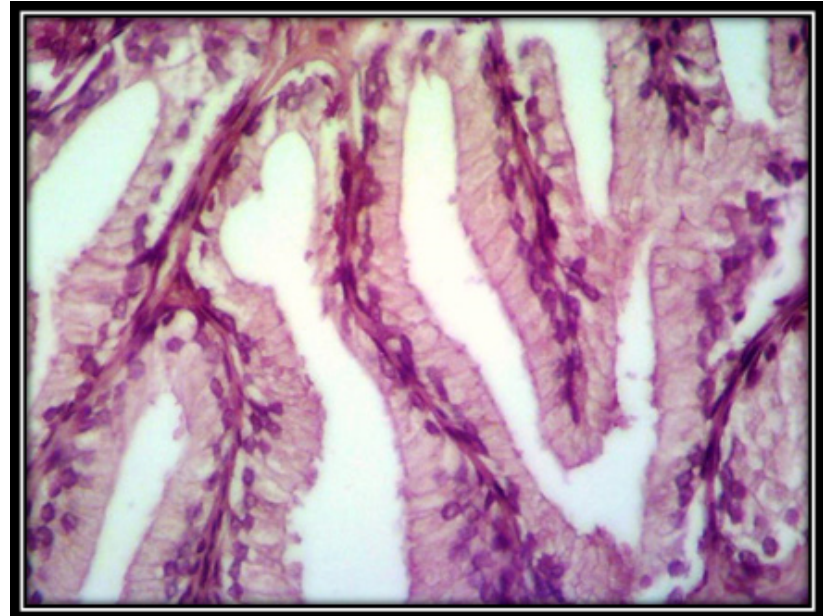

Fig. 9: Negative immunohistochemical expression of OCT4 in nuclei of normal tissue around PCa in NPCA samples. X400

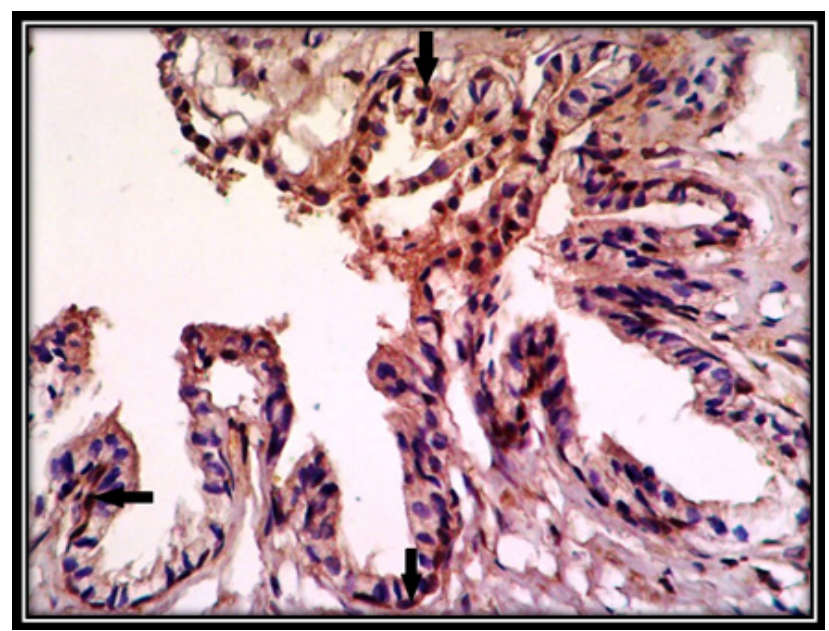

Fig.10: Immunohistochemical expression of OCT4 in NPCA group shows 1+ weak nuclear reactivity (black arrows) of OCT4 polyclonal antibody. X400

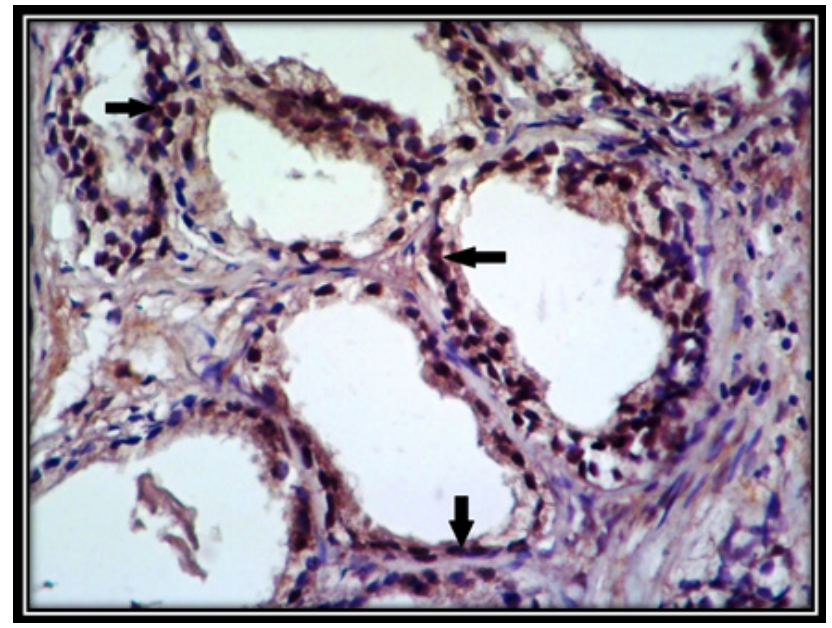

Fig. 11: Immunohistochemical expression of OCT4 in NPCA group shows $2+$ moderate nuclear reactivity (black arrows) of OCT4 polyclonal antibody. X400

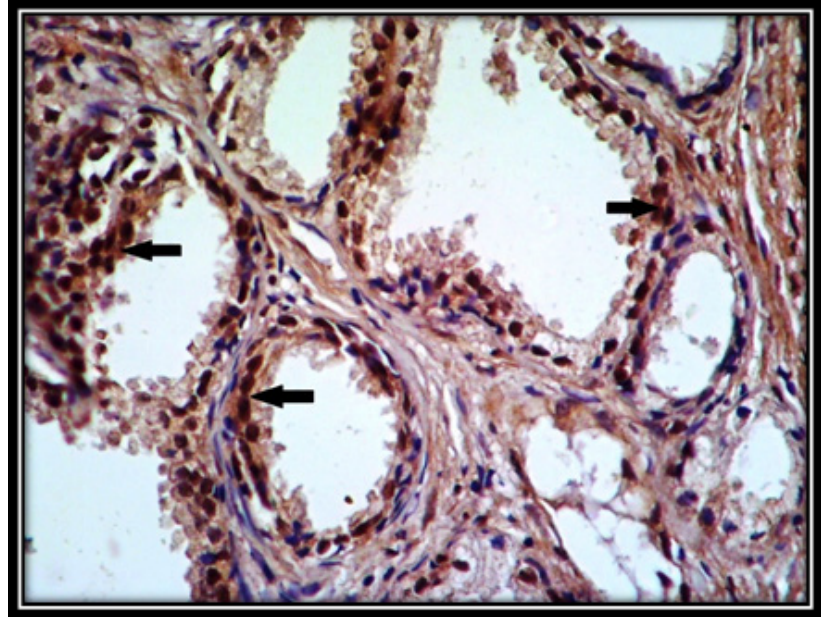

Fig. 12: Immunohistochemical expression of OCT4 in NPCA group shows $3+$ strong nuclear reactivity (black arrows) of OCT4 polyclonal antibody. X400

\section{DISCUSSION}

\section{Age distribution}

Benign prostatic hyperplasia (BPH) is one of the most common disorders and major reason of sickness in old males which may produce bladder outflow blockade and inferior urinary tract signs ${ }^{[15]}$. The occurrence of BPH is related to age ${ }^{[16]}$, in that the occurrence of hyperplastic changes of BPH in autopsy readings increases from approximately $20 \%$ in males aged $41-50$ years, to $50 \%$ in males aged 51-60, and to $>90 \%$ in males older than $80^{[17]}$. More than $70 \%$ of the male population aged over 60 has medical or laboratory histological evidence of BPH.

Prostate cancer $(\mathrm{PCa})$ is the most prevalent occurring male non-cutaneous tumor in the Western world ${ }^{[18,19]}$ and the fourth malignant tumor affecting Iraqi men ${ }^{[20]}$. Considerate etiologies of both conditions is essential to decreasing the subsequent problem of illness and death. The appearance of BPH upsurges severely with increasing age. The frequency of $\mathrm{PCa}$ also noticeably rises with age, being three times of extent higher for the age range from 40-79 years than for those aged less than 40 years $^{[21,22]}$. There is a lot of correlation in the epidemiological reasons of $\mathrm{BPH}$ and $\mathrm{PCa}^{[23]}$, but the ultimate risk factor for both illnesses is increasing the age of individuals.

Our results were in line with previous explanations of literature ${ }^{[15,17,19,20,22,23]}$ that showed an increasing incidence of both BPH and prostatic carcinoma in the ages above 60 , after that age; the chance of developing PCa becomes more common than any other cancer in males ${ }^{[24]}$. There was no statistically significant difference between the age of cases with BPH than those with prostatic carcinoma in our work.

\section{Expression of OCT4 in BPH and NPCA groups}

Octamer 4 relates to the family of Pit-Oct-Unc-domain transcription factors and had been expressed in embryonic stem cell and germ cells ${ }^{[25]}$. A number of researches had 
shown that OCT4 is crucial in retaining the self-renewal and pluripotency of embryonic stem cells ${ }^{[26]}$. Formally, it has also been revealed that cancer cells that expressed OCT4 may be fundamental in cancer development ${ }^{[27]}$. The gene, OCT4, is one of an essential gene regulatory network, and is necessary for embryogenesis, pluripotency and self-renewal of cells ${ }^{[26]}$. OCT4 preserves pluripotency in embryogenesis; the up regulation of OCT4 marks in differentiation to the primitive endoderm and mesoderm, whiledownregulationencourages the declineofpluripotency and dedifferentiation into the trophectoderm ${ }^{[28]}$. A recent study examined the role of OCT4 as a wholesome stem cell marker by viewing its appearance in differentiated cells ${ }^{[29]}$. The important transcriptional regulator OCT4 preserves "stemness" condition.

Cancer stem cells had been recognized in a range of many malignancies ${ }^{[14]}$. They are a minor group of cancer cells with stem cell features, which are a probable cause of recurrence in malignant patients ${ }^{[30]}$. Earlier readings had also recommended that certain tumors, as well as prostate cancer ${ }^{[14,31]}$, expressed OCT4 concurrently ${ }^{[32,33]}$, and its expression has been linked with the differentiation of tumors ${ }^{[34]}$. This gene is important for cancer cell survival ${ }^{[35]}$, that claims the significance of tumor stem and progenitor cells in prostatic carcinogenesis. This higher score of appearance is not essentially related with stem cell behavior ${ }^{[36]}$, but might be related to the deregulation proteins that deliver certain kind of growing benefit to cancer cells ${ }^{[37]}$.

The results of this work showed more OCT4 expression in the NPCA group in comparison to BPH group, and it was statistically significant. Fifty percent of NPCA cases moderately express OCT4 which was significantly different from BPH cases; in contrast, $36 \%$ of BPH group cases were negative for OCT 4 and $30 \%$ of cases expressed it weakly. So, higher total score obtained in NPCA group $(P$-value $=0.036$ significant statistically $)$. These results agree with the work of Hatefi et al.; Kim and Nam; Miyazawa et al.; Wang et al.; Sedaghat et al. ${ }^{[30,38,39,40,41]}$. On the other hand, these findings disagree with those of Ugolkov et al. who demonstrated a high expression level of OCT4 in BPH than in prostatic carcinoma ${ }^{[14]}$.

According to the idea of field cancerization of the normal tissue adjacent to cancer (where "adjacent" was defined as $\geq 3-\mathrm{mm}$ distant from tumor) (safety margin) ) $^{[42]}$, field cancerization which is the presence of transformed cells adjacent to the primary tumor, and it is hypothesized to be a mediator of disease progression and relapse ${ }^{[43]}$. This process involves multiple complicated molecular events leading to the transformation of a completely normal cell into a cancer cell. Cancer stem cells are capable of tumor initiation and migration, both of which are necessary for regulating field cancerization ${ }^{[42]}$. Loss of heterozygosity, microsatellite alterations, chromosomal instability, and telomerase activity are the established molecular events used to differentiate and characterize cancer stem cell-mediated field cancerization ${ }^{[43]}$, depending on this information and in patients with increased suspicion of prostate cancer but negative histological biopsy, documentation of field cancerization could deal the suspected zones by surgeons for repeated biopsy.

The source of prostate cancer origin remains unidentified and had taken us to a series of theories ${ }^{[44]}$. Prostatic adenocarcinomas are often multifocal, show the identical immunohistochemical outline as benign glandular tissues, and loss markers of basal cell, such as p63 and cytokeratin $34 \beta^{[45]}$. This specifies that prostatic cancer might grow from transformed benign glandular tissues. Yet, many pluripotency markers, like CD117, CD44 and Oct3/4, had been revealed to be expressed in prostatic cancer, demonstrating that prostate cancer might arise from shared stem cell like or intermediate cells ${ }^{[46]}$.

According to the findings of some researchers, immunohistochemical appearance of OCT4 isoforms associated with pathological and biochemical considerations, predominantly biochemical recurrencefree survival. Cases with high levels of OCT4B expression had lower level of Gleason scores and reduced possibility of suffering biochemical relapse ${ }^{[47]}$. OCT4A+ OCT4Bcases had the shorter biochemical recurrence-free survival, and positive expression of OCT4B was not dependent prognostic element for biochemical recurrence-free survival in the multiple vitiating investigation ${ }^{[48]}$. They decided that OCT4B expression was a stronger marker of good prediction, and the existence of it was related with a reduced probability of biochemical relapse. Accordingly, OCT4B could symbolize a potent experimental prognostic factor for PCa Patients ${ }^{[47]}$. Though, OCT4 is a nuclear marker and appeared clearly in the nuclei of BPH and NPCA group cases of this work, but the difference in the OCT4 isoforms might demonstrate the OCT4 in both nucleus and cytoplasm of the epithelial cells. OCT4A antibody displayed specific nuclear staining ${ }^{[48]}$. Alternatively, OCT4B marker produced specific cytoplasmic expression in cancer cells and OCT4 antibody produced cytoplasmic and nuclear staining ${ }^{[47]}$. Gao et al. explained that the OCT4B isoform is up regulated underneath genotoxic tension, supporting apoptosis of cell by $\mathrm{p} 53^{[48]}$. This kid of cell strain produces DNA damage and resulted in DNA mutations and tumorigenesis; cells might reply to DNA damage in 2 ways: either DNA apoptosis or repair; when the harm is repairable, cells might arrest cell cycle to adding more time for DNA repair, and when the harm is irreparable, they go on apoptosis to avoid that damaged DNA from being delivered on $^{[47]}$. Accordingly, the elevation of apoptosis by OCT4B creates a protective appliance all over the entire entity. Conversely, cells expressing OCT4A had hardly been documented in human malignant and benign prostate tissues $^{[49]}$. The number of these cells expressed OCT4A had been revealed to rise in prostate adenocarcinoma with higher Gleason scores ${ }^{[49]}$. Hence, differences occur in researches studying the character and appearance of definite stem cell and progenitor cell markers in prostate cancer cells. 
Ugolkov et al. ${ }^{[14]}$ described that OCT4 nuclear staining expression was evidently linked with benign prostatic conditions, and not in prostatic cancer. In our work, OCT4 higher expression was found in the NPCA and BPH samples; however, significant differences were observed in its expression between NPCA and BPH cases ${ }^{[14]}$. Instead, Rasti et al. demonstrated that renal cell cancer cases with higher OCT4 and NANOG (transcription factor in embryonic stem cells) expressions level in cancer tissues had suggestively lower survival rate and metastasis-free survival range ${ }^{[50]}$

Latest researches designate that miRNAs show a substantial part in stem cell regulation, comprising prostatic cancer stem cells, and may clarify part of the molecular regulatory mechanisms of cancer stem cells ${ }^{[51]}$. The unusual appearance of miRNAs in tumor proposes that they role as either tumor-suppressor or oncogenes ${ }^{[52]}$. miRNAs like miR-134, miR-296, and miR-470 are shared in regulation of target genes crucial for pluripotency and stem cell function comprising OCT4, SOX2, and NANOG ${ }^{[51,53,54]}$.

OCT4 in prostatic cancer is essential because of its obvious role in carcinogenesis and tumor progression. Supplementary, OCT4 isoforms need to be inspected distinctly in pathological labs via particular antibodies touching each antigen isoform and suitable confirmation by molecular biology procedures. Additionally, OCT4B is a valued but not dependent marker of good disease prognosis and its estimation in the specimen may be vital for defining the most appropriate medical and operating attitude for cases with prostatic cancer ${ }^{[47]}$.

Detection of OCT4 in tumor cells and tissues indicated its enrichment in a subpopulation of undifferentiated tumor-initiating cells that critically account for tumor initiation, metastasis, and resistance to anticancer therapies through its participation in various tumor-initiating cells functions such as its self-renewal and survival, epithelialmesenchymal transition and metastasis, and drug resistance development is implicated from considerable OCT4 knockdown and overexpression-based studies ${ }^{[55]}$.

\section{CONCLUSIONS}

This study provided evidence that:

1. Over expression of OCT4 in normal tissue around prostatic carcinoma than benign tissue in $\mathrm{BPH}$.

2. Increasing age is one of important common causes of both BPH and prostatic cancer in addition to other epidemiological and pathophysiological causes.

\section{ACKNOWLEDGEMENTS}

This work was not supported by research grants.

\section{CONFLICTS OF INTEREST}

There are no conflicts of interest

\section{REFERENCES}

1. Yoo, T.K., Cho, H.J. Benign prostatic hyperplasia: from bench to clinic. Korean $\mathrm{J}$ Urol (2012) 53, 139-148.

2. Bray F, Ferlay J, Soerjomataram I, Siegel RL, Torre LA, Jemal A. Global cancer statistics 2018: GLOBOCAN estimates of incidence and mortality worldwide for 36 cancers in 185 countries. CA cancer J Cli, in press (2018).

3. Miah S, Catto J. BPH and prostate cancer risk. Indian J Urol. (2014) 30(2): 214-218.

4. Tai MH, Chang CC, Kiupel M, Webster JD, Olson LK, Trosko JE. Oct4 expression in adult human stem cells: evidence in support of the stem cell theory of carcinogenesis. Carcinogenesis (2005) 26:495-502.

5. Lee J, Kim HK, Rho JY, Han YM, Kim J. The human OCT-4 isoforms differ in their ability to confer self-renewal. J Biol Chem (2006) 281:33554-65.

6. Koo BS, Lee SH, Kim JM, Huang S, Kim SH, Rho YS, Bae WJ, Kang HJ, Kim YS, Moon JH, Lim YC. Oct4 is a critical regulator of stemness in head and neck squamous carcinoma cells. Oncogene (2015) [Epub ahead of print]

7. Abubaker K, Luwor RB, Zhu H, McNally O, Quinn MA, Burns CJ, Thompson EW, Findlay JK, Ahmed N. Inhibition of the JAK2/STAT3 path-way in ovarian cancer results in the loss of cancer stem cell-like characteristics and a reduced tumor burden. BMC Cancer (2014) 14: 317.

8. Ben-Porath I, Thomson MW, Carey VJ, Ge R, Bell GW, Regev A, Weinberg RA. An embryonic stem cell-like gene expression signature in poorly differentiated aggressive human tumors. Nat Genet (2008) 40: 499-507.

9. $\mathrm{Hu} \mathrm{T}$, Liu S, Breiter DR, Wang F, Tang Y, Sun S. Octamer 4 small interfering RNA results in can-cer stem cell-like cell apoptosis. Cancer Res (2008) 68: 6533-40.

10. Patru C, Romao L, Varlet P, Coulombel L, Ra-poni E, Cadusseau J, Renault-Mihara F, Thirant C, Leonard $\mathrm{N}$, Berhneim A, Mihalescu-Maingot M, Haiech J, Bièche I, Moura-Neto V, Daumas-Duport C, Junier MP, Chneiweiss H. CD133, CD15/SSEA-1, CD34 or side populations do not resume tumor-initiating properties of long-term cultured cancer stem cells from human malignant glioneuronal tumors. BMC Cancer (2010) 10: 66.

11. Zhou F, Donmgu Y, Jjunlang, Xinliu Z, Chen HS, Zhang. Expression and prognostic value of tumor stem cell markers ALDH1 and CD133 in colorectal carcinoma. Int J Clin Exp Pathol. (2014) 7(6): 2976-2986. 
12. Mutlak SS, Hasan NA,AL-Hijazi AY. BiochemicalAnd Immunohistochemical Evaluation Of Transforming Growth Factor- Betal And Tumor Necrosis FactorAlpha In Dental Diseases. IJRPC (2015) 5(4), 736-752

13. Hameed AF, Ibraheem MM, Ahmed BS. C-MYC and BCL2 Expression in Normal Tissue Around Proliferative Breast Conditions in Relation to ER, $P R$ in a Sample of Iraqi Women. UK Journal of Pharmaceutical and Biosciences (2018) 6(3): 01-06.

14. Ugolkov AV, Eisengart LJ, Luan C, Yang XJ. Expression analysis of putative stem cell markers in human benign and malignant prostate. Prostate (2011) $1 ; 71(1): 18-25$

15. Khaleel FM, AL-Shammri IA, Mohammed NAG, Estimation of Testosterone, Estradiol and some Markers in Sera of Iraqi Patients with Benign Prostatic Hyperplasia. Baghdad Science Journal (2013) 10(4): 1162-1171.

16. Abdul-Aziz MM, Helal NN. Insulin resistance and hyperinsulinemia in non-diabetic non-obese benign prostatic hyperplasia patients. Tikrit Medical Journal (2008) 14(2):138- 142.

17. Presti JC, Kane CJ, Shinohara K, Carrol PR. Neoplasm of the prostate gland. In: Tanagho EA, McAninch JW (eds). Smith's General Urology. $17^{\text {th }}$ ed. San Francisco: Lange Medical Book/ McGraw-Hill (2008) 348.

18. Velonas VM, Woo HH, dos Remedios CG, Assinder SJ. Current status of biomarkers for prostate cancer. Int J Mol Sci (2013) 14: 11034-11060.

19. Patel ND, Parsons JK . Epidemiology and etiology of benign prostatic hyperplasia and bladder outlet obstruction. Indian J Urol (2014) 30: 170-176.

20. Al-Abdin OZ and Al-Beeshi IZ. Prostate cancer in the Arab population. Saudi Med J (2018) 39 (5): 453-458.

21. Rebbeck TR. Conquering cancer disparities: new opportunities for cancer epidemiology, biomarker, and prevention research. Cancer Epidemiol Biomarkers Prev (2006) 15: 1569-1571.

22. Tao ZQ, Shi AM, Wang KX, Zhang WD. Epidemiology of prostate cancer: current status. Eur Rev Med Pharmacol Sci (2015) 19: 805-812.

23. Alcaraz A, Hammerer P, Tubaro A, Schröder FH, Castro $\mathrm{R}$. Is there evidence of a relationship between benign prostatic hyperplasia and prostate cancer? Findings of a literature review. Eur Urol (2009) 55: 864-873.

24. Walsh PC, Worthington JF. Dr. Patrick Walsh's Guide to Surviving Prostate Cancer. 4th edition, Prostate cancer Foundation (2011).

25. Scholer HR, Balling R, Hatzopoulos AK, Suzuki N, Gruss P. Octamer binding proteins confer transcriptional activity in early mouse embryo-genesis. EMBOJ (1989) 8: 2551-7.
26. Boiani M, Scholer HR. Regulatory networks in embryo-derived pluripotent stem cells. Nat Rev Mol Cell Biol (2005) 6: 872-84.

27. Monk M and Holding C. Human embryonic genes re-expressed in cancer cells. Oncogene (2001) 20: 8085-8091.

28. Pesce M and Scholer HR. Oct-4: control of totipotency and germline determination. Mol Reprod Dev (2000) 55: 452-457.

29. Zangrossi S, Marabese M, Broggini M, Giordano R, D'Erasmo M, Montelatici E, Intini D, Neri A, Pesce M, Rebulla P and Lazzari L. Oct-4 expression in adult human differentiated cells challenges its role as a pure stem cell marker. Stem Cells (2007) 25: 1675-1680.

30. Hatefi N, Nouraee N, Parvin M, Ziaee SAM, Mowla SJ. Evaluating the Expression of Oct4 as a Prognostic Tumor Marker in Bladder Cancer. Iranian Journal of Basic Medical Sciences (2012) 15(6):1154-1161.

31. Ma Y, Liang D, Liu J, Axcrona K, Kvalheim G, Stokke T, Nesland JM and Suo Z. Prostate cancer cell lines under hypoxia exhibit greater stem-like properties. PLoS One (2011) 6: e29170.

32. Tysnes BB. Tumor-initiating and - propagating cells: cells that we would like to identify and control. Neoplasia (2010) 12: 506-515.

33. Mallanna SK and Rizzino A. Systems biology provides new insights into the molecular mechanisms that control the fate of embryonic stem cells. J Cell Physiol (2012) 227: 27-34.

34. Till JE. Stem cells in differentiation and neoplasia. J Cell Physiol Suppl (1982) 1: 3-11.

35. Gu G, Yuan J, Wills M and Kasper S. Prostate cancer cells with stem cell characteristics reconstitute the original human tumor in vivo. Cancer Res (2007) 67: 4807-4815.

36. Yin X, Li YW, Zhang BH, Ren ZG, Qiu SJ, Yi Y and Fan J. Coexpression of stemness factors Oct4 and Nanog predict liver resection. Ann Surg Oncol (2012) 19: 2877-2887.

37. Ezeh UI, Turek PJ, Reijo RA and Clark AT. Human embryonic stem cell genes OCT4, NANOG, STELLAR, and GDF3 are expressed in both seminoma and breast carcinoma. Cancer (2005) 104: 2255-2265.

38. Kim RJ and Nam JS. OCT4 Expression Enhances Features of Cancer Stem Cells in a Mouse Model of Breast Cancer. Lab Anim Res (2011) 27(2): 147-152.

39. Miyazawa K, Tanaka T, Nakai D, Morita N, Suzuki $\mathrm{K}$. Immunohistochemical expression of four different stem cell markers in prostate cancer: High expression of NANOG in conjunction with hypoxia-inducible factor- $1 \alpha$ expression is involved in prostate epithelial malignancy. Oncology Letters (2014) 8: 985-992. 
40. Wang Q, Zhang JG, Wang W. Expression and significance of S100P, CD147, and OCT4 in different prostate cancer tissue TNM stages. Genetics and Molecular Research (2015) 14 (2): 6844-6851.

41. Sedaghat S, Gheytanchi E, Asgari M, Roudi R, Keymoosi H, Madjd Z. Expression of Cancer Stem Cell Markers OCT4 and CD133 in Transitional Cell Carcinomas. Applied Immunohistochemistry \& Molecular Morphology. 25(3):196-202, MARCH 2017.

42. Haaland CM, Heaphy CM, Butler KS, Fischer EG, Griffith JK, Bisoffi M. Differential gene expression in tumor adjacent histologically normal prostatic tissue indicates field cancerization. International Journal Of Oncology (2009) 35: 537-546.

43. Jones AC, Trujillo KA, Phillips GK, Fleet TM, Murton JK, Severns V, Shah SK, Davis MS, Smith AY, Griffith JK, Fischer EG, Bisoffi M. Early Growth Responseland Fatty Acid Synthase Expression is Altered in Tumor Adjacent Prostate Tissue and Indicates Field Cancerization. Prostate 1 (2012) 72(11): 1159-1170.

44. Lawson DA and Witte ON. Stem cells in prostate cancer initiation and progression. J Clin Invest (2007) 117: 2044-2050.

45. Miki J, Furusato B, Li H, Gu Y, Takahashi H, Egawa $\mathrm{S}$, Sesterhenn IA, McLeod DG, Srivastava S and Rhim JS. Identification of putative stem cell markers, CD133 and CXCR4, in hTERT-immortalized primary nonmalignant and malignant tumor-derived human prostate epithelial cell lines and in prostate cancer specimens. Cancer Res (2007) 67: 3153-3161.

46. Hurt EM, Kawasaki BT, Klarmann GJ, Thomas SB and Farrar WL. CD44+ CD24(-) prostate cells are early cancer progenitor/stem cells that provide a model for patients with poor prognosis. Br J Cancer (2008) 98: 756-765.

47. De Resende MF, Chinen LTD, Vieira S, Jampietro J, da Fonseca FP, Vassallo J, Campos LC, Guimarães GC, Soares FA, Rocha RM. Prognostication of OCT4 isoform expression in prostate cancer. Tumor Biol. (2013) DOI 10.1007/s13277-013-0817-9.

48. Gao Y, Wei J, Han J, Wang X, Su G, Zhao Y, et al. The novel function of OCT4B isoform-265 in genotoxic stress. Stem Cells. (2012) 30(4):665-72.

49. Sotomayor P, Godoy A, Smith GJ and Huss WJ. Oct4A is expressed by a subpopulation of prostate neuroendocrine cells. Prostate (2009) 69: 401-410.

50. Rasti A, Mehrazma M, Madjd Z, Abolhasani M, Zanjani LS, Asgari M. Co-expression of Cancer Stem Cell Markers OCT4 and NANOG Predicts Poor Prognosis in Renal Cell Carcinomas. Scientific Reports (2017) 8:11739.

51. Chakraborty C, Chin KY, Das S. miRNA-regulated cancer stem cells: understanding the property and the role of miRNA in carcinogenesis. Tumour Biol (2016) 37:13039-13048.

52. Tao ZQ, Shi AM, Li R, Wang YQ, Wang X, Zhao J. Role of microRNA in prostate cancer stem/ progenitor cells regulation. Eur Rev Med Pharmacol Sci (2016) 20:3040-3044.

53. Kong YW, Ferland-McCollough D, Jackson TJ, Bushell M. microRNAs in cancer management. Lancet Oncol (2012) 13:e249-e258.

54. Gandellini P, Giovannetti E, Nicassio F. MicroRNAs in cancer management: big challenges for small molecules. Biomed Res Int (2015) 2015:982156.

55. Wang YJ, Herlyn M. The emerging roles of Oct4 in tumor-initiating cells. Am J Physiol Cell Physiol. (2015) 1; 309(11): C709-C718. 


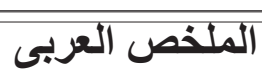

\section{التعبير عن علامة الخلايا الجذعية OCT4 في البروستات الحميدة فرط التنسج والأنسجة الطبيعية حول سرطان البروستاتا في عينة من المرضى العراقيين

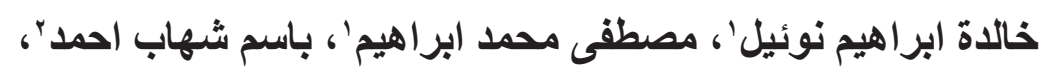

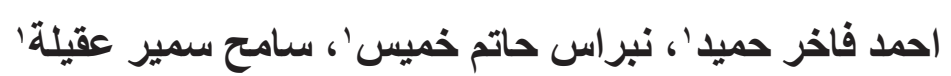

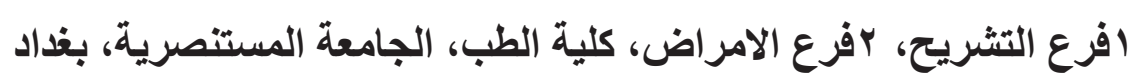

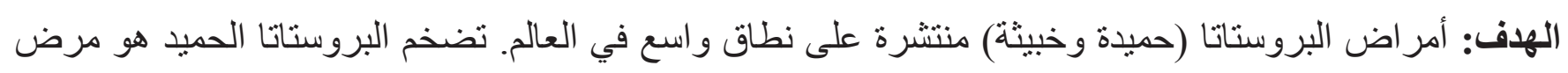

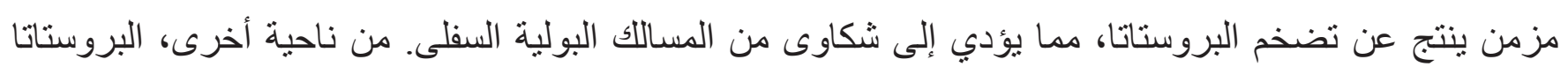

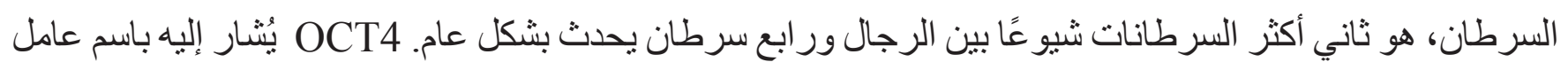

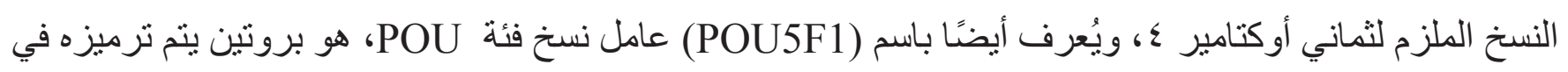
البشر بو اسطة الجين POU5F1. هذا البروتين مفصل تحليليًا في التجديد الذاتي لخلايا جذعية جنينية غير متمايزة.

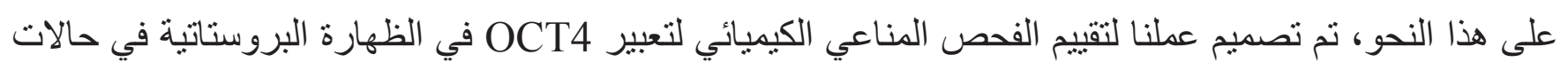

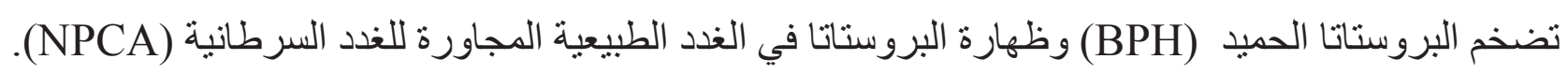

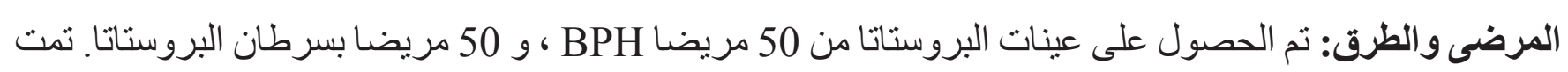

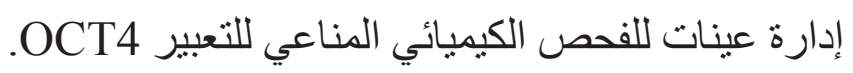

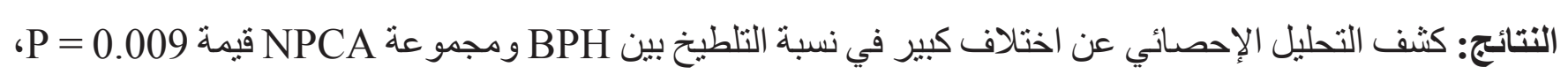
وكان هناك تعبير تلطيخ كبير لـ OCT4 في مجمو عة DPCA مقارنة بمجمو عة BPH قيمة

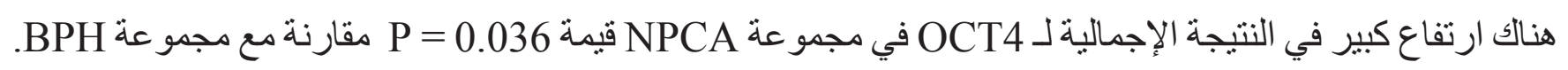
الاستتتاجات: يتم التعبير عن OCT4 في الأنسجة الطبيعية حول سرطان البروستاتا بالمقارنة مع الأنسجة الحميدة في لئي BPH وبالتالي يمكن استخدام OCT4 كمؤشر للخلايا الجذعية لجين نسيجية البروستاتا. 